\title{
THE EFFECT OF UNDERNUTRITION ON MUSCULAR FORCE
}

\author{
A STUDY OF THE INFLUENCE OF LOW DIETS, OR THE ALLEN METHOD OF \\ TREATMENT ON THE PHYSICAL VIGOR \\ OF DIABETICS * \\ JOHN R. WILLIAMS, M.D. \\ ROCHESTER, N. Y.
}

As is now generally known, the cardinal features of the Allen method of treating diabetics are fasting, and the feeding of low diets and diets so modified as to meet the metabolic needs of the individual. While fasting and low feeding have been suggested and employed by various other workers in this field, the persistent and continued use of these dietary measures to the point of making and maintaining the patient both acid and sugar free, as employed by Allen, is a radical departure from former methods of treatment.

Among the many fears which this unique treatment has excited in the minds of both clinicians and patients is that the persistent use of the low diet would gradually and seriously weaken the patient. Untreated diabetics are accustomed to eating even larger quantities of food than are normal individuals. The diet of normal individuals of course varies widely with the age and is influenced greatly by such factors as sex, habit and occupation. Few healthy persons, however, eat less than 1,500 calories per day, many eat as much as 4,000 calories per day, and the normal range may be considered as between 2,000 and 3,000 calories. According to Lusk," "the average starvation metabolism of a vigorous man at light work and weighing 70 kilograms, approximates 2,240 calories, or 32 calories per kilogram, and the maintenance requirement is between 11.1 and 14.4 per cent. above the starvation minimum. This would amount to from 2,488 to 2,562 calories, or from 35.5 to 36.6 calories per kilogram of body weight in the case of the individual just referred to." It is quite generally accepted that the healthy adult individual needs, for the proper maintenance of weight and physical vigor, about 40 calories of food per kilo of body weight, and growing children from 50 to 90 calories per kilo of body weight.

All recent studies show that few diabetics can tolerate much more than half these quantities of food. In some mild cases the patients

* Submitted for publication April 19, 1917.

1. Lusk, Graham: The Science of Nutrition, 1909, p. 210. 
improve to the degree that between 2,000 and 2,500 calories can be eaten without provoking a glycosuria; in the majority of mild cases they do better, however, on diets ranging between 1,500 and 2,000 calories per day.

In advanced cases the patients are obliged to live on less food in order to remain sugar free. It is common to find patients who can tolerate not more than 1,000 calories per day, and there are numerous instances of individuals who have had to live on less (Table 1).

\section{TABLE 1.-Food Tolerance in Diabetics}

Showing total food tolerance in calories of a series of diabetic patients when discharged from the hospital, who still survive. The urine of each patient was free of both sugar and ketone bodies.

\begin{tabular}{|c|c|c|c|c|}
\hline \multirow{2}{*}{$\begin{array}{l}\text { Total Calories } \\
\text { in Diet }\end{array}$} & \multirow{2}{*}{$\begin{array}{c}\text { Number } \\
\text { Males } \\
\text { Over } \\
15 \text { Years }\end{array}$} & \multirow{2}{*}{$\begin{array}{l}\text { Number } \\
\text { Females } \\
\text { Over } \\
15 \text { Years }\end{array}$} & \multicolumn{2}{|c|}{$\begin{array}{l}\text { Children Under } \\
15 \text { Years }\end{array}$} \\
\hline & & & Males & Females \\
\hline 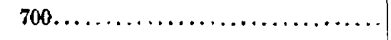 & 4 & 1 & 0 & 1 \\
\hline $800 \ldots \ldots \ldots \ldots \ldots \ldots \ldots$ & 0 & 1 & 0 & 0 \\
\hline $900, \ldots \ldots \ldots \ldots \ldots \ldots \ldots \ldots \ldots \ldots \ldots \ldots \ldots \ldots$ & $I$ & 2 & 0 & 0 \\
\hline $1000 \ldots \ldots \ldots \ldots \ldots \ldots \ldots$ & 1 & 2 & $\mathbf{0}$ & 0 \\
\hline $1100, \ldots \ldots \ldots \ldots \ldots \ldots \ldots$ & 2 & 3 & 1 & 1 \\
\hline $1200 \ldots \ldots \ldots \ldots \ldots \ldots \ldots \ldots \ldots \ldots \ldots$ & 4 & 1 & 1 & 1 \\
\hline $1300 \ldots \ldots \ldots \ldots \ldots \ldots \ldots \ldots \ldots$ & 0 & 7 & $\mathbf{0}$ & $\mathbf{0}$ \\
\hline $1400 \ldots \ldots \ldots \ldots \ldots \ldots \ldots \ldots \ldots$ & 1 & 3 & $\mathbf{0}$ & $\mathbf{0}$ \\
\hline . $\ldots \ldots \ldots$ & 4 & 5 & $\mathbf{0}$ & $\mathbf{0}$ \\
\hline $1600 \ldots \ldots \ldots \ldots \ldots \ldots \ldots$ & 1 & 3 & 2 & 0 \\
\hline $1700 \ldots \ldots \ldots \ldots \ldots$ & 5 & 7 & 1 & 0 \\
\hline $1800 \ldots \ldots \ldots \ldots \ldots \ldots \ldots \ldots \ldots$ & 9 & 0 & 1 & $\mathbf{0}$ \\
\hline $1900 \ldots \ldots \ldots \ldots \ldots \ldots \ldots \ldots$ & 4 & 1 & 1 & 0 \\
\hline $2000 \ldots \ldots \ldots \ldots \ldots \ldots$ & 4 & 0 & 0 & $\mathbf{0}$ \\
\hline $2100 \ldots \ldots \ldots \ldots \ldots \ldots \ldots$ & 3 & 0 & 0 & 0 \\
\hline $2200 \ldots \ldots \ldots \ldots \ldots \ldots \ldots \ldots \ldots \ldots$ & 1 & 0 & 0 & 0 \\
\hline $2400 \ldots \ldots \ldots \ldots \ldots \ldots \ldots \ldots \ldots \ldots \ldots \ldots$ & 2 & 0 & 0 & 0 \\
\hline Total cases ................... & 46 & 36 & 7 & 3 \\
\hline
\end{tabular}

Comment.-It will be seen that 4 males and 1 female over 15 years of age and 1 female under 15 years of age, in order to remain sugar and acid free, were compelled to live on diets approximating 700 calories. Likewise 4 males and 1 female over 15 years of age, and 1 male and 1 female under 15 years of age had dietary limitations of 1,200 calories, and so on. This table illustrates very well the caloric tolerance of diabetic patients who are favorable for treatment, and it affords a fairly reliable measure of the deprivation which they must undergo. These diets range from 5 to 40 per cent. under the supposed minimum starvation metabolism requirements. 
In the minds of many clinicians the question has arisen, What effect does the persistent use of a low diet have on the physical vigor of the diabetic? The fear is often expressed that its continued use must eventually exhaust the patient. Muscular weakness is one of the commonest symptoms of the disease; therefore the influence of underfeeding is a pertinent question and worthy of consideration.

During the past year the writer has endeavored to gain some tangible evidence on this point. At the suggestion of Dr. Aleŝ Hrdlickka,

\section{TABLE 2.-Dynamometer Tests}

Case 1522; male, aged 18. Table showing a comparison over a long period of time of the total calories in the diet, weight, urine and lung air findings with the measure of muscular force as determined by tests of grip strength.

\begin{tabular}{|c|c|c|c|c|c|c|}
\hline \multirow{2}{*}{$\begin{array}{c}\text { Day of } \\
\text { Treatment }\end{array}$} & \multirow{2}{*}{$\begin{array}{l}\text { Diet in } \\
\text { Calories }\end{array}$} & \multirow{2}{*}{$\begin{array}{l}\text { Weight, } \\
\text { Pounds }\end{array}$} & \multirow{2}{*}{$\begin{array}{c}\text { Strength Test, } \\
\text { Kg. }\end{array}$} & \multicolumn{2}{|c|}{ Urine } & \multirow{2}{*}{$\begin{array}{l}\mathrm{CO}_{2} \text { in } \\
\text { Lung Air, } \\
\text { Mm. }\end{array}$} \\
\hline & & & & $\begin{array}{c}\text { Sugar, } \\
\text { Gm. }\end{array}$ & $\begin{array}{l}\text { NHs, } \\
\text { Gm. }\end{array}$ & \\
\hline 397 & 1,700 & $1421 / 2$ & R $36-L 24$ & 25 & 1.48 & 38.6 \\
\hline 402 & 1,310 & $1421 / 2$ & R $37-\mathrm{L} 30$ & 0 & 0 & 44.6 \\
\hline 409 & 1,585 & 146 & R $36-$ L 32 & 0 & 0 & 40.0 \\
\hline 415 & 1.585 & 146 & R $38-\mathbf{L} 32$ & 0 & 0 & 43.2 \\
\hline 421 & 1,585 & 145 & R $38-$ L 30 & 0 & 0 & - \\
\hline 430 & 1,585 & 147 & R $36-$ L 30 & 0 & 0 & 44.5 \\
\hline 437 & 1,600 & 147 & R $40-$ L 32 & 0 & 0 & 38.7 \\
\hline 759 & 1,640 & $1421 / 2$ & R $46-$ I 34 & 0 & 0 & 45.1 \\
\hline
\end{tabular}

Comment: Case 1522 presents interesting features. The patient left the hospital after a stay of twenty-one days on a diet approximating 1,800 calories. This he increased rapidly by the addition of fat to 2,500 calories. The excessive fat apparently produced a cholesterinemia and was subsequently reduced to about 1,800 calories. The patient suffered from two serious "grippe colds," which for several weeks made it necessary for him to live on a diet ranging from 600 to 1,200 calories. One of these infections immediately preceded the period covered by the data in Table 2 . It will be seen that while this patient's weight remained fairly constant, he gained considerably in muscular force, although he had been on a diet averaging 1,600 calories, considerably below the figures given by Lusk for the average starvation metabolism of a man doing light work, which in this patient's case would amount to 2,080 calories. It will be noted that this patient had been under treatment and on a comparatively low diet for more than two years. At the date of the last examination, he presented the usual evidences of physical vigor observable in a young man, and these observations are confirmed by an increase in his muscular force as measured by the strength of grip which, it will be noted, is well within the normal range. There are no evident reasons for thinking that this patient has in any way suffered because of the long period of undernutrition to which he had been subjected; on the contrary, it is highly probable that a serious diabetic condition has been ameliorated and a metabolic collapse averted. 
assistant curator in charge of the Division of Anthropology, United States National Museum, Washington, a Collin dynamometer was used for the purpose. With this instrument the maximum pressure which can be exerted by each hand can be determined. This test, also known as the strength of grip, is used by psychologists and anthropologists as an index of general bodily strength. According to Hrdlickka, ${ }^{2}$ adult

\section{TABLE 3.-Dynamometer Tests}

Case 1881; girl, aged 16. Table showing a comparison of the total calories in the diet, weight, urine and lung air findings with the measure of muscular force as determined by tests of grip strength.

\begin{tabular}{|c|c|c|c|c|c|c|}
\hline \multirow{2}{*}{$\underset{\text { Day of }}{\text { Treatment }}$} & \multirow{2}{*}{$\begin{array}{l}\text { Diet in } \\
\text { Calories }\end{array}$} & \multirow{2}{*}{$\begin{array}{l}\text { Weight, } \\
\text { Pounds }\end{array}$} & \multirow{2}{*}{$\begin{array}{c}\text { Strength Test, } \\
\text { Kg. }\end{array}$} & \multicolumn{2}{|c|}{ Urine } & \multirow{2}{*}{$\begin{array}{c}\mathrm{CO}_{2} \text { in } \\
\text { Lung Air, } \\
\text { Mm. }\end{array}$} \\
\hline & & & & Sugar, & $\begin{array}{l}\mathrm{NH}_{3}, \\
\mathrm{Gm} .\end{array}$ & \\
\hline 2 & 30 & 90 & R $1.5-$ L 14 & $\ldots$ & 0.57 & 29.5 \\
\hline 3 & 205 & 90 & R $17-$ L 15 & $\ldots$ & 1.17 & 29.5 \\
\hline 4 & 226 & $871 / 2$ & R $16-L 15$ & $\ldots$ & 0.94 & 28.8 \\
\hline 5 & 312 & $851 / 2$ & R $15-L 12$ & $\ldots$ & 1.29 & 29.5 \\
\hline 6 & 445 & $851 / 2$ & R $16-$ L 14 & $\ldots$ & 1.20 & 39.8 \\
\hline 7 & 670 & $86 \%$ & R $18-L 17$ & $\cdots$ & 0.87 & 36.9 \\
\hline 8 & 683 & $863 / 4$ & R $16-$ I 15 & $\cdots$ & $\ldots \ldots$ & 40.4 \\
\hline 9 & 874 & 87 & R 18 - L 16 & $\ldots$ & $\ldots \ldots$ & 38.0 \\
\hline 11 & 814 & $85^{1 / 2}$ & R $16-$ L 16 & $\ldots$ & ..... & 35.6 \\
\hline 12 & 1,084 & $851 / 2$ & R $17-\mathbf{L} 15$ & $\ldots$ & $\ldots \ldots$ & 34.9 \\
\hline 13 & 1.034 & $851 / 4$ & R. $19-\mathbf{L} 17$ & $\ldots$ & $\ldots \ldots$ & 48.4 \\
\hline 14 & 1,161 & $853 / 4$ & R $17-$ L 16 & $\ldots$ & $\ldots \ldots$ & 39.6 \\
\hline 16 & 1,334 & 85 & R $21-\mathbf{L} 16$ & $\ldots$ & $\ldots \ldots$ & 37.2 \\
\hline 22 & 1,696 & $853 / 4$ & R $30-$ L 18 & $\ldots$ & $\ldots \ldots$ & 41.9 \\
\hline
\end{tabular}

Comment: Diabetes was discovered in this child three months before entering the hospital. During this period she was alternately starved and overfed. Weakness was an important symptom. After the sixth day she was required to take systematic dumbbell exercise daily, together with walks in the fresh air. The test of muscular force confirms the striking improvement in the child's physical condition.

healthy American-born whites give records ranging, for pressure in the right hand, in males, from 35 to 60 ; in females, from 25 to $38 \mathrm{~kg}$.; for pressure in the left hand, in males, from 30 to 50 ; in females, from 20 to $30 \mathrm{~kg}$. A healthy right-handed white man from 25 to 40 years

2. Hrdlickka, Aleŝ: Physiological and Medical Observation Among the Indians of Southwestern United States and Northern Mexico, Bureau of American Ethnology, Bull. 34, p. 143. 
of age, used to some muscular work or exercise, will press with the right hand 50 to 55 , with the left hand 40 to $45 \mathrm{~kg}$.; a healthy righthanded white woman between similar limits of age and with good muscular tone, can press with the right hand from 30 to 35 , and with the left hand 20 to $30 \mathrm{~kg}$. As age advances, the muscular force in general becomes gradually less.

The test of muscular force was made in the following manner: In each instance a Collin dynamometer was used. Tests were made in

\section{TABLE 4.-Dynamometer Tests}

Case 1517; girl, aged 17. Table showing a comparison of the total calories in the diet, body weight, urine and lung air findings, with the measure of muscular force as determined by tests of grip strength.

\begin{tabular}{|c|c|c|c|c|c|c|}
\hline \multirow{2}{*}{$\begin{array}{l}\text { Day of } \\
\text { Treatment }\end{array}$} & \multirow{2}{*}{$\begin{array}{c}\text { Diet in } \\
\text { Calories }\end{array}$} & \multirow{2}{*}{$\begin{array}{l}\text { Weight, } \\
\text { Pounds }\end{array}$} & \multirow{2}{*}{$\begin{array}{l}\text { Strength Test, } \\
\text { Kg. }\end{array}$} & \multicolumn{2}{|c|}{ Urine } & \multirow{2}{*}{$\begin{array}{c}\mathrm{CO}_{2} \text { in } \\
\mathrm{Lung} \mathrm{Air} \\
\mathrm{Mm} .\end{array}$} \\
\hline & & & & $\begin{array}{c}\text { Sugar, } \\
\text { Gm. }\end{array}$ & $\begin{array}{l}\mathrm{NH}_{3}, \\
\mathrm{Gm} .\end{array}$ & \\
\hline 127 & 990 & 95 & R 18 - L 11 & 8 & 0.75 & 33.2 \\
\hline 128 & 895 & 95 & R I8 - L 14 & 0 & 0 & 34.8 \\
\hline 129 & 895 & 93 & R 19 - L 11 & 5 & 0.43 & 36.1 \\
\hline 140 & 915 & 93 & R 18 - L 12 & 13 & 0.60 & 40.0 \\
\hline 142 & 878 & 93 & L $19-\mathrm{J}, 12$ & 10 & 0.27 & 37.8 \\
\hline 143 & 100 & 93 & R $18-L 16$ & 0 & 2.24 & - \\
\hline 144 & 530 & 94 & L 21 - L 19 & 0 & 2.19 & 38.9 \\
\hline 145 & 435 & $934 / 2$ & R $22-$ L 18 & 4 & 0.61 & 30.0 \\
\hline 146 & 671 & 92 & R $22-\mathrm{L} 17$ & 8 & 0.92 & 38.0 \\
\hline 147 & 100 & 93 & R $22-$ L 17 & 0 & 2.20 & 33.3 \\
\hline 148 & 802 & 94 & R $19-$ L 18 & 0 & 1.80 & 37.8 \\
\hline 151 & 712 & 92 & $\ldots \ldots+\ldots \ldots$ & 0 & 1.53 & 37.8 \\
\hline 159 & 355 & 98 & R $24-\mathbf{L} 17$ & 0 & 0.58 & - \\
\hline 161 & 975 & $911 / 2$ & R $22-$ L 17 & $\theta$ & 0 & 41.7 \\
\hline
\end{tabular}

COMMENT: This young woman had a serious diabetes for nearly one year before it was discovered and before treatment was instituted. It will be observed that on the 127 th day of her treatment, when the observations on muscular force in her case were begun, she was well advanced. This persistent low metabolic state the writer attributes to a persistent chronic infection which was localized beneath a very expensive piece of dental bridge work, and which the parents were unwilling to have removed. In spite of her very low diet, this patient lost very little in weight and maintained to a surprising degree her physical vigor, as evidenced by the strength tests. This patient led an active outdoor life, playing tennis mildly, and indulging in other forms of recreation. Shortly after the date of the last observation, already noted, the patient abandoned the treatment, ate indiscriminately, rapidly lost in weight and strength and a few months later died. This case illustrates the fact that a patient, even on a very low diet suited to the metabolic needs of the individual, may gain in physical vigor, and that a diet in excess of these limitations may cause loss of physical strength and even death. 
the morning. The spirit of competition was encouraged among patients so as to excite their best efforts. Two or three trials were made with each hand and the best effort recorded. The Collin dynamometer is graduated to read in kilograms. On the clinical charts and in the tabulations accompanying this paper, R 25-L 20 means that with the right hand the patient registered 25 kilograms, and with the left hand 20 kilograms. The dial should be held toward the palm with the little set screw between the fingers. This ensures a more accurate reading and avoids hurt to the hand. The tests, where possible, were made with the patient in a standing position, with the arms held away fron! the body and not supported in any manner. These precautions are

\section{TABLE 5.-Dynamometer 'Tests}

Case 1787; woman, aged 52. Table showing a comparison of the total calories in the diet, body weight, urine and lung air findings, with the measure of muscular force as determined by tests of grip of strength.

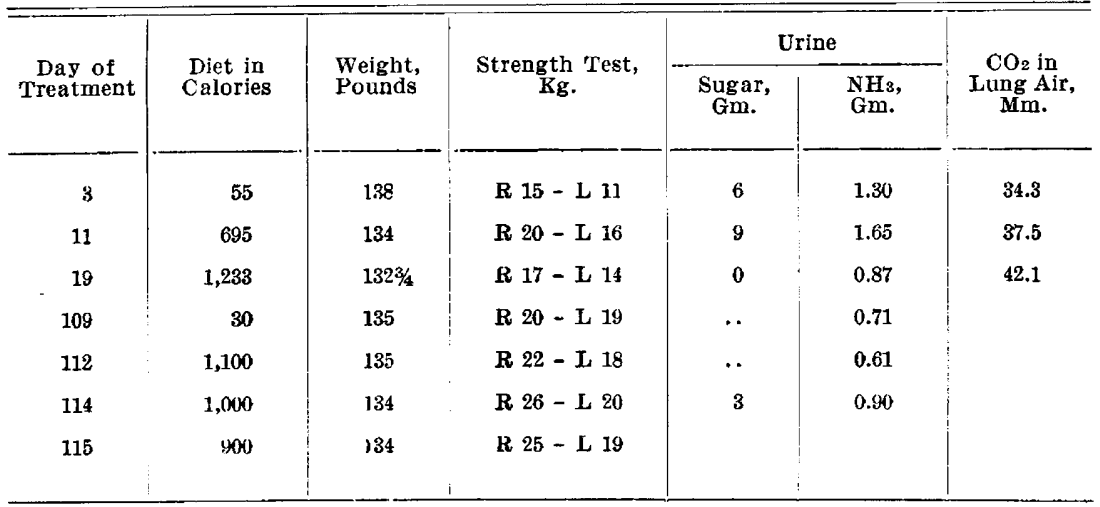

Comment: Diabetes was discovered in this patient six months before the date of the foregoing observations. The chief symptom was weakness. It will be noted that the patient had a mild acidosis when she entered the hospital. During the 115 days in which she was more or less under observation, she lived on not more than 60 per cent. of the total calories thought necessary to maintain her minimum metabolism, yet she gained noticeably in physical vigor, as is evidenced by her strength tests.

necessary for accurate results. Tests of patients who are unduly worried or after sleepless nights are of value as indicating the depressing physical effect of anxiety and dissipation, and may prove misleading unless properly interpreted. They should be used guardedly in measuring the normal muscular force of patients. This was well illustrated in one of the cases studied, a sturdy male of 57 years. This man was able repeatedly to exert a pressure of 36 kilograms with his right hand and 26 with his left hand. On the day after he was told 
that his blood gave a marked positive Wassermann reaction and its significance, and after twenty-four hours of worry, the greatest pressure he could exert with his right hand was 28 kilograms and with his left, 22 kilograms.

\section{TABLE 6.-Dynamometer Tests}

Case 1680; woman aged 19. Table showing a comparison over a period of 598 days of the total calories in the diet, body weight, urine and lung air findings, with the measure of muscular force as determined by tests of grip of strength.

\begin{tabular}{|c|c|c|c|c|c|c|}
\hline \multirow{2}{*}{$\begin{array}{c}\text { Day of } \\
\text { Treatment }\end{array}$} & \multirow{2}{*}{$\begin{array}{l}\text { Diet in } \\
\text { Calories }\end{array}$} & \multirow{2}{*}{$\begin{array}{l}\text { Weight, } \\
\text { Pounds }\end{array}$} & \multirow{2}{*}{$\begin{array}{c}\text { Strength Test, } \\
\text { Kg. }\end{array}$} & \multicolumn{2}{|c|}{ Orine } & \multirow{2}{*}{$\begin{array}{c}\mathrm{CO}_{2} \text { in } \\
\text { Lung Air, } \\
\text { Mm. }\end{array}$} \\
\hline & & & & $\begin{array}{c}\text { Sugar, } \\
\text { Gm. }\end{array}$ & $\begin{array}{l}\text { NH3, } \\
\text { Gm. }\end{array}$ & \\
\hline 300 & 140 & 120 & R 18 - I 14 & $\ldots \ldots$ & 0.84 & 44.0 \\
\hline 528 & 565 & 108 & R $10-\mathrm{L} 12$ & 0 & $\ldots \ldots$ & 35.6 \\
\hline 526 & 982 & 104162 & $\mathrm{R} 12-\mathrm{L} 8$ & 0 & & \\
\hline 537 & 1,248 & 100 & R $15-$ L 12 & Trace & $\ldots \ldots$ & 43.0 \\
\hline 544 & 973 & $991 / 4$ & R $12-\mathrm{L} 11$ & Trace & $\ldots \ldots$ & 42.9 \\
\hline 549 & 1,105 & 103 & R $12-$ L 12 & Trace & 0.53 & 43.2 \\
\hline 557 & 498 & 99 & R $12-L 10$ & Trace & $\ldots \ldots$ & 38.5 \\
\hline 568 & 1,234 & 100 & R $14-$ L 9 & Trace & 0.15 & 44.1 \\
\hline 575 & 1,303 & $1011 / 2$ & R $15-\mathrm{L} 10$ & Trace & 0.47 & 42.5 \\
\hline 582 & 1,155 & 100 & R $16-$ L 11 & $\ldots \ldots$ & $\ldots \ldots$ & 44.9 \\
\hline 587 & 1,436 & 101 & R $12-$ L 10 & 0 & 0.54 & \\
\hline 594 & 1,350 & $981 / 2$ & R $12-\mathrm{L} 9$ & $\ldots \ldots$ & 0.44 & 38.7 \\
\hline 598 & 1,429 & $98^{1 / 2}$ & R 15 - L 11 & 0 & 0.49 & 43.0 \\
\hline
\end{tabular}

Comment: This case presents most unusual features. Diabetes was discovered in this young woman in May, 1915. She entered the hospital for treatment in July, 1915. After a stay of one month she went home, sugar and acid free, on a diet of about 2,000 calories. Events subsequently proved that she was being overfed on fat and this was reduced. From Nov. 1, 1915, to Jan. 1, 1917, she lived on a diet averaging under 1,000 calories; much of the time it was less than 800 calories. At one time, omitting the fat entirely from the diet served to increase her carbohydrate metabolism from 20 to $70 \mathrm{gm}$. About Dec. 1, 1916, it became almost impossible to keep her sugar free when any carbohydrate was added to the diet. The patient was readmitted to the hospital and examination showed that there was a very low tolerance for protein. When the protein intake did not exceed $30 \mathrm{gm}$. the patient could tolerate upward of $50 \mathrm{gm}$. of carbohydrate and a total of 1,400 calories, whereas $45 \mathrm{gm}$. of protein and $30 \mathrm{gm}$. of carbohydrate caused small amounts of sugar to appear in the urine. The first test of muscular force was made after the patient had been under treatment for 390 days. She apparently was then in much better physical tone than when later observations were made. It is quite probable that this state of protein irritation existed for some time before its discovery. Before the 547th day of the treatment, the patient was eating from 65 to $90 \mathrm{gm}$. of protein daily, and probably was imperfectly utilizing it. After the 547th day of treatment, the protein intake was reduced to $30 \mathrm{gm}$., or less, with a general improvement in the condition of the patient, and a marked increase in the total calories which could 
be safely ingested. Is it not probable that this apparent disturbance in protein metabolism and the low intake on which the patient was compelled to live had much to do with the material lessening of her muscular force?

\section{TABLE 7.-Dynamometer Tests}

Case 1709; man, aged 33. Table showing a comparison of the total calories in the diet, body weight, urine and lung air findings, with the measure of muscular force as determined by tests of grip strength.

\begin{tabular}{|c|c|c|c|c|c|c|}
\hline \multirow{2}{*}{$\begin{array}{c}\text { Day of } \\
\text { Treatment }\end{array}$} & \multirow{2}{*}{$\begin{array}{l}\text { Diet in } \\
\text { Oalories }\end{array}$} & \multirow{2}{*}{$\begin{array}{l}\text { Weight, } \\
\text { Pounds }\end{array}$} & \multirow{2}{*}{$\begin{array}{c}\text { Strength Test, } \\
\text { Kg. }\end{array}$} & \multicolumn{2}{|c|}{ Urine } & \multirow{2}{*}{$\begin{array}{c}\mathrm{CO}_{2} \text { in } \\
\text { Lung Air } \\
\text { Mm. }\end{array}$} \\
\hline & & & & $\begin{array}{l}\text { Sugar, } \\
\text { Gm. }\end{array}$ & $\begin{array}{l}\mathrm{NH}_{3}, \\
\mathrm{Gm} .\end{array}$ & \\
\hline 947 & 458 & $881 / 4$ & R $14-$ L 10 & - & - & 46.4 \\
\hline 967 & 485 & $783 / 4$ & $\mathrm{R} 9-\mathrm{L} 7$ & - & - & 40.4 \\
\hline 864 & 1,410 & 81 & R 8 - L 8 & - & 0.91 & 44.0 \\
\hline 978 & 1.186 & 80 & R $10-\mathrm{L} 6$ & 1 & - & 89.8 \\
\hline
\end{tabular}

Comment: Advanced diabetics who have a low food tolerance, who constantly exceed their metabolic limitations and who frequently show both glycosuria and ketonuria, usually become very weak and remain so. Case 1709 is a good illustration of this fact. The patient, a man, 33 years of age, began the treatment of his diabetes, June 29,1914 . In the beginning the danger of eating to the limit of tolerance was not realized, with the result that the patient was constantly fed up to or but little below that point, which was about 2.500 calories. The frequent recurrence of sugar in the urine was constantly associated with a lowering tolerance and increasing muscular weakness, so that in February, 1915, the patient was unable to eat more than 1,300 calories of food without glycosuria manifesting itself. During the summer of 1915 the patient for several weeks abandoned the diet, so that by August he had developed into a condition bordering on coma. He had a very marked acidosis, and it was with difficulty that he was made sugar and acid free. Aug. 25, 1916, his alveolar air was $21.4 \mathrm{~mm}$. and he excreted in the twenty-four hours $2.57 \mathrm{gm}$. of ammonia. At this time he was very weak, indeed almost dead. Sept. 2, 1916, after being sugar and acid free for several days, and with a normal alveolar air $(46.4 \mathrm{~mm}$.), the first strength test was made. The patient was then 40 pounds under his usual weight and was on a diet of 458 calories. With his right hand he registered $14 \mathrm{~kg}$., and $10 \mathrm{~kg}$. with his left. During his stay in the hospital at this time it was evident that he could not safely tolerate more than 950 calories. He went home, however, and again began overeating to the point of having every few days a mild glycosuria and ketonuria, which he would correct by fasting. Under this plan of constant irritation he remained weak, as will be seen by the accompanying table. The first strength test was made after the patient had been under observation for 947 days, and the last test was made on the 978th day of observation. This table, unfortunately, only exhibits data of one brief hospital period, during which time he was under strict control. After two previous periods of hospital care, and following the one in which the above data were obtained, the patient relapsed into the habit of overeating, to the point of producing a mild glycosuria and ketonuria. Death finally resulted from exhaustion and coma. The career of this patient is typical, in so far as physical vigor is concerned, of the majority of patients who eat to the point of keeping their bodies in a state of metabolic exhaustion. The writer has notes on several similar cases, in all of which overeating led to a striking loss of muscular vigor, and, eventually, to exhaustion and death. 
TABle 8.-Comparison of Muscular Force as Determined by Strength of Grip with Age, Weight and Food Tolerance in a Series of Cases

\begin{tabular}{|c|c|c|c|c|c|c|c|}
\hline $\begin{array}{l}\text { Case } \\
\text { No. }\end{array}$ & $\begin{array}{c}\text { Day } \\
\text { of } \\
\text { Treat. } \\
\text { ment }\end{array}$ & Age & $\begin{array}{l}\text { Weight, } \\
\text { Net } \\
\text { Pounds }\end{array}$ & $\begin{array}{l}\text { Weight,* } \\
\text { per Cent.; } \\
\text { Over (t) } \\
\text { Under (-) } \\
\text { Normal }\end{array}$ & $\begin{array}{c}\text { Minimum } \\
\text { Normal } \\
\text { Oaloric } \\
\text { Needs of } \\
\text { Patient }\end{array}$ & $\begin{array}{c}\text { Oaloric } \\
\text { Tolerance } \\
\text { of } \\
\text { Patient }\end{array}$ & $\underset{\mathbf{~ S t r e n g t h} \text { Test, }}{\text { Stre }}$ \\
\hline $\begin{array}{l}\text { Males } \\
\quad 1877\end{array}$ & 14 & 57 & $1201 / 2$ & $6+$ & 1,740 & 1,846 & R $28-\mathrm{L} 22$ \\
\hline 1686 & 19 & 50 & 180 & $20+$ & 2,618 & 1,668 & R $35-$ L 32 \\
\hline 1878 & 17 & 60 & $192 \% / 4$ & $11+$ & 2,794 & 1,950 & R $35-$ L 30 \\
\hline 1843 & 36 & 60 & $1421 / 2$ & $14-$ & 2,070 & 1,727 & R $30-$ L 24 \\
\hline 1845 & 26 & 27 & 132 & $24-$ & 1,920 & 2,089 & $R 46-L 38$ \\
\hline 1866 & 16 & 67 & $130 \% / 2$ & $20-$ & 1,898 & 1,261 & R $39-$ L 31 \\
\hline 1672 & 18 & 50 & 167 & $6+$ & 2,429 & 2,194 & R 37- L 32 \\
\hline 1536 & 36 & 50 & $1311 / 4$ & $23-$ & 1,907 & 1,858 & R $42-$ L 37 \\
\hline 1729 & 176 & 48 & 267 & $57+$ & 3,884 & 1,210 & R $53-$ L 43 \\
\hline 1688 & 287 & 23 & 133 & $9-$ & 1,982 & 1,800 & R 45- L 38 \\
\hline 1522 & 769 & 20 & 139 & $6-$ & 2,019 & 1,640 & R $46-$ L 34 \\
\hline 1882 & 16 & 19 & 118 & $18-$ & 1,715 & 1,778 & R $32-\mathrm{L} 28$ \\
\hline 1681 & 49 & 10 & $531 / 2$ & $21-$ & 777 & 618 & $R 6-L 6$ \\
\hline$\underset{1787}{\text { Females }}$ & 115 & 52 & 134 & $4-$ & 1,949 & 960 & R $26-120$ \\
\hline 1890 & 18 & 32 & $883 / 4$ & $36-$ & 1,290 & 1,141 & R $20-L_{15}$ \\
\hline 1816 & 26 & 47 & $113 \frac{1}{4}$ & $13-$ & 1,648 & 1,775 & R $22-\mathrm{L} 16$ \\
\hline 1799 & 22 & 68 & 160 & $3-$ & 2,326 & 1,075 & R 12 - L 15 \\
\hline 1545 & 67 & 39 & $753 / 4$ & $45-$ & 1,094 & 736 & R $16-\mathrm{L}_{14}$ \\
\hline 1582 & 208 & 29 & $1083 / 4$ & $17-$ & 1,580 & 1,105 & R $18-\mathrm{L} 15$ \\
\hline 1739 & 214 & 62 & $2031 / 2$ & $31+$ & 2,960 & 1,540 & R $30-$ L 20 \\
\hline 1680 & 588 & 20 & 98 & $24-$ & 1,424 & 1,429 & R 15 - L 11 \\
\hline 1507 & 313 & 20 & 113 & $12-$ & 1,644 & 950 & R 17 - L 18 \\
\hline 1567 & 42 & 20 & 95 & $25-$ & 1,385 & 1,320 & R $18-\mathbf{L}_{16}$ \\
\hline 1517 & 181 & 18 & 87 & $27-$ & 1,264 & 975 & R $22-\mathbf{L} 17$ \\
\hline 1758 & 28 & 13 & $691 / 2$ & $20-$ & 1,011 & 1,210 & R $10-$ I 11 \\
\hline 1718 & 28 & 14 & 68 & $29-$ & 989 & 848 & R $11-\mathbf{L} 6$ \\
\hline
\end{tabular}

* Determined by dividing net weight by normal weight based on sex, age and height, according to the standards of the New York Life Insurance Company.

$t$ The minimum normal pressure exerted by healthy men between 25 and 40 years of age, according to Hrdlicka, is right hand, 35 to $60 \mathrm{~kg}$; left hand, 20 to $35 \mathrm{~kg}$.; women between 25 and 40 years of age, right hand, 25 to $38 \mathrm{~kg}$; left hand, 12 to $20 \mathrm{~kg}$.

Comment: Diabetics as a rule are underweight. Allen has pointed out that patients have less difficulty in keeping sugar free when they are thin than when they are fat. In the foregoing tables the weights normal and actual are compared with the evidences of muscular force as shown by the strength of grip. It will be noted that although these patients, for the most part, were thin, some of them very thin, and were living on diets much below the normal minimum requirement ( 32 calories per kilo of body weight), they nearly all gave quite satisfactory responses to the test of muscular force. 


\section{SUMMARY AND CONCLUSION}

1. This investigation supports the common clinical observation that diabetics, as a rule, are distinctly physically weaker than normal persons. Loss of body musculature may partly explain this, but it is probable that the lessened amount of food metabolized in these cases does not provide sufficient energy for the normal exercise requirements of the body. There appears to be a direct relationship between food tolerance and muscular vigor. As food tolerance increases, so does also muscular tone. Decline in food tolerance is accompanied by loss of physical vigor.

2. The continued use of a low diet for many months, even though it fall far short of the energy requirements of the body, provided it is within the physiologic limitations of the body to metabolize it, will cause an appreciable gain in muscular tone, although the amount of physical effort that such a person may be able to put forth may be considerably below the normal. This is in accord with clinical experience that nutrition within the tolerance of the patient gives the greatest comfort, strength and sense of well being and, as Joslin has pointed out, the greatest expectation of life.

3. These observations also show that while diabetics living on a diet below normal physiologic requirements possess a diminished muscular vigor, feeding them beyond their metabolic limitations causes not only a further reduction in their tolerance for food, but also an even greater loss of strength. This is contrary to the view commonly held by both physicians and laymen. There is no justification for the common notion that overfeeding causes even a temporary increase in comfort or body strength.

The general conclusion from this inquiry is that diabetics gain in physical vigor as they become and remain sugar free, while overfeeding causes a definite and often a serious loss of strength.

Attention is called to the use of the dynamometer as a simple and fairly trustworthy method of measuring muscular tone or physical vigor. For this purpose, it has a wide range of application in the study of metabolic and other diseases, and in my hands has yielded valuable information in the study of both diabetes and nephritis. 